\title{
CONCENTRATED SOLAR POWER (CSP) INNOVATION ANALYSIS IN SOUTH AFRICA
}

\author{
0.0. Craig ${ }^{1 * \#}$, A.C. Brent ${ }^{1,2}$ \& F. Dinter ${ }^{3}$
}

\section{ARTICLE INFO}

Article details

Submitted by authors 8 Sep 2016

Accepted for publication 2 Jun 2017

Available online $\quad 31$ Aug 2017

Contact details

Corresponding author

18623786@sun.ac.za

Author affiliations

1 The Centre for Renewable and Sustainable Energy Studies (CRSES), and Department of Industrial Engineering, Stellenbosch University, South Africa

2 Department of Sustainable Energy Systems, School of Engineering and Computer Science, Victoria University of Wellington, New Zealand

3 The Solar Thermal Energy Research Group (STERG), Department of Mechanical Engineering, Stellenbosch University, South Africa

\# The author was enrolled for a PhD degree in Engineering in the Engineering Management and Sustainable Systems research group in the Department of Industrial Engineering, Stellenbosch University
ABSTRACT

South Africa aims to generate 42 per cent of its electricity from renewable energy technology sources by 2030 . Concentrating solar power (CSP) is one of the major renewable energy technologies that have been prioritised by South Africa, given the abundant solar resources available in the region. Seven CSP plants have been, or are being, built; three of them are already connected to the national grid. However, the impacts of this technology on South African research, development, and innovation have not been investigated to date. This paper thus analyses the CSP technologies in South Africa in terms of the existing technology adoption models and diffusion strategies, used by government and its agencies, to improve the development and deployment of these technologies. It is found that CSP has been treated generally like other renewable energy technologies through the Renewable Energy Independent Power Producer Procurement Programme (REIPPPP), although a tariff plan for CSP plants of the future has been made. No specific technology diffusion or adoption model for CSP was found; so this paper explores how it can be developed.

\section{OPSOMMING}

Suid-Afrika het ten doel om 42 persent van sy elektrisiteit uit hernubare energie tegnologie bronne te genereer teen 2030. Gekonsentreerde sonkrag (CSP) is een van die grootste hernubare tegnologie energieë wat reeds geprioritiseer is deur Suid-Afrika, as gevolg van ' $n$ oorvloedige son hulpbron beskikbaar in die streek. Sewe CSP aanlegte is, of word, gebou en drie van hulle is reeds gekoppel aan die nasionale netwerk. Maar die impak van hierdie tegnologie op Suid-Afrikaanse navorsing, ontwikkeling en innovasie is tot dusvêr nie ondersoek nie. Hierdie artikel voer dus 'n ontleding van die CSP tegnologie in Suid-Afrika uit in terme van die bestaande tegnologie aanneming modelle en verspreiding strategieë, wat gebruik word deur die regering en sy agentskappe, om die ontwikkeling en implementering van hierdie tegnologie te verbeter. Dit is bevind dat CSP, in die algemeen, behandel word soos ander hernubare energie tegnologie deur middel van die Hernubare Energie Onafhanklike Krag Verskaffer Aankoop Program (REIPPPP), hoewel ' $n$ tarief plan vir CSP aanlegte van die toekoms wel gemaak is. Geen spesifieke tegnologie diffusie of aanneming model vir CSP is gevind nie, en hierdie artikel ondersoek hoe dit ontwikkel kan word.

South Africa (SA) intends to achieve $17,800 \mathrm{MW}$ of renewable energy by the year 2030 , and so the South African Department of Energy (DoE) has prioritised some renewable energy technologies (RETs) in its Renewable Energy Independent Power Producer Procurement Programme (REIPPPP). These RETs include concentrating solar power (CSP), solar photovoltaic (PV), biomass, and onshore wind 
technologies [1]. The reason for the inclusion of CSP technologies, which is a new and developing technology, is that SA receives an annual average direct normal irradiation (DNI) of $2,816 \mathrm{kWh} / \mathrm{m}^{2}$ in the Northern Cape region, as shown in Figure 1. This amount is far higher than the DNI available in either Spain or the United States of America, where the best locations for CSP technologies only receive an annual average of approximately 2,100 and 2,700 $\mathrm{kWh} / \mathrm{m}^{2}$ respectively [2], and both nations have CSP plants operating at full capacity.

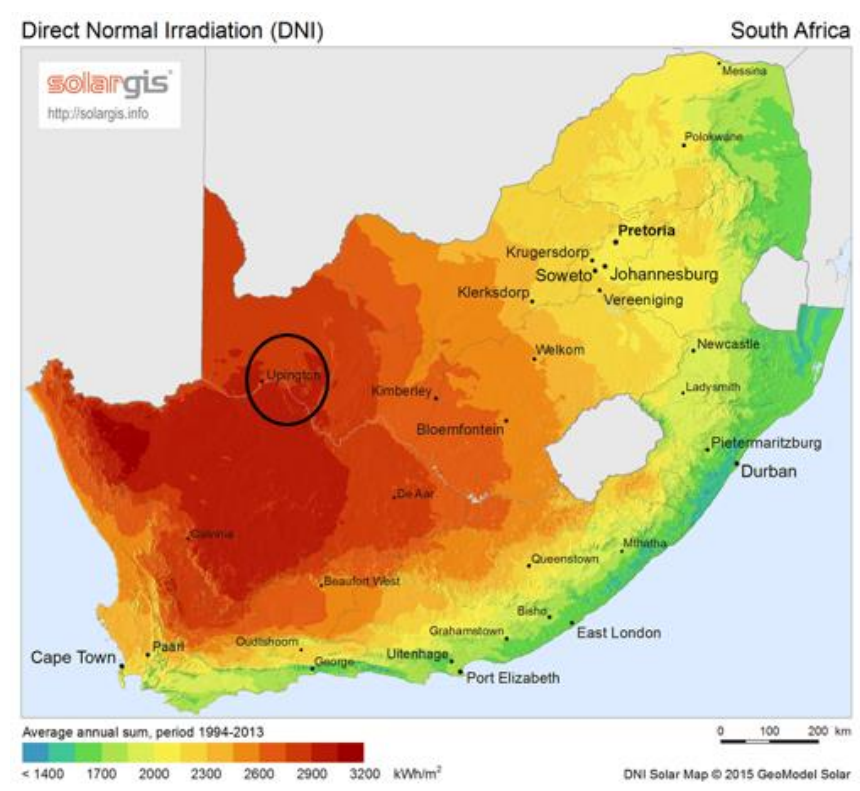

Figure 1: Average daily direct normal irradiation (DNI) for SA [3] (see online for colour image)

Renewable energy technologies, when connected to existing systems, or grids, often have effects on the overall system, because these technologies have characteristics that are radically different from conventional generating systems with respect to intermittency [4]. Shum and Watanabe [5] subsequently suggested that, as long as renewable energy technologies seek either to complement or to challenge the existing technology status quo, they will have to compete with the existing complementary assets and infrastructures that accompany the established technologies. Thus an important strategy that could aid the penetration of renewable energy technologies would be to develop a specific technology adoption model for each type of renewable energy, because their technology transfer processes are different [6].

\subsection{Objectives of this paper}

This paper seeks to perform an innovation analysis on CSP technology in SA by examining the existing operations, establishing the impacts of this innovation on local research and development (R\&D), and suggesting possible improvement methods, thus answering the following research questions:

- What is the current state of CSP in SA?

- What are the impacts of CSP technology in SA with respect to research, development, and innovation?

- What role have the government and government agencies played in the development of CSP in SA?

- What is the way forward?

\subsection{Paper outline}

The paper starts by showing the state of CSP compared with other RETs in SA. Section 3 discusses the impacts and challenges of CSP, along with its innovation analysis. Section 4 highlights the efforts of the South African government to accelerate the deployment of CSP. Section 5 discusses the evolving research environment by suggesting possible adoption techniques and identifying the gap in CSP adoption in SA. The conclusion section presents a summary, and the necessary recommendations for future research. 
In order to achieve its renewable energy target, the SA Department of Energy (DoE) has already rolled out bids in four successive windows for RET generation, through the REIPPPP [1]. Solar PV, CSP, and wind RETs have dominated these bids, compared with other RETs (landfill gas, biogas, and biomass), as shown in Figure 2.

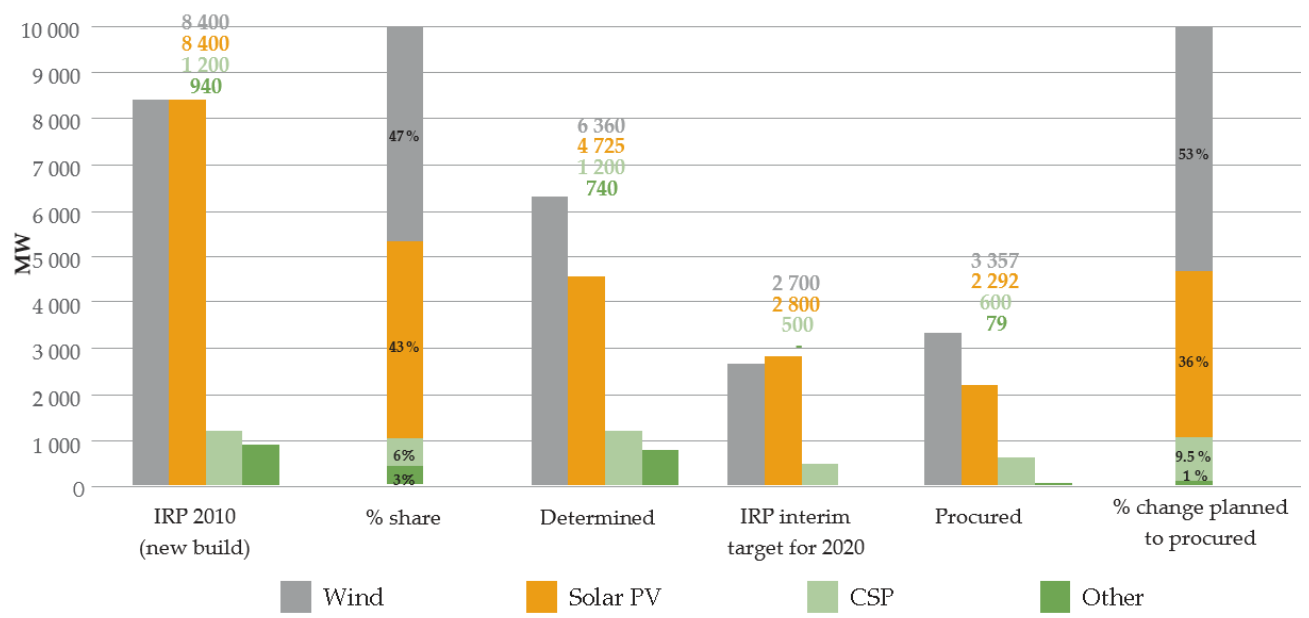

Figure 2: RET mix in SA (planned and procured, excluding hydro) [1] (see online for colour image)

Out of the three dominating RETs, solar PV and wind contribute the most to the national grid, while CSP lags behind. Ibenholt [7] identified that wind energy has established itself as a matured and global RET, and this has decreased the cost of that technology over the years. As at June 2015, a total of $790 \mathrm{MW}$ of electricity in the SA power grid was supplied by wind energy [1]. Figure 2 shows that 53 per cent of the procured RETs in SA's REIPPPP bids was for wind energy. The relatively low price of this RET has given it a competitive edge over other RETs, with an average tariff of $71 \mathrm{c} / \mathrm{kWh}$, which shows that the tariff has fallen by half since the first bid, as shown in Figure 3a.

In addition, by mid-2015, over $960 \mathrm{MW}$ of electricity in the SA power grid had been supplied by PV; thus PV supplies more than one third (approximately 35 per cent) of the total energy generated from renewable energy sources in SA. Also, a total capacity of 2,290 MW of solar PV has been allocated in all the bid windows; and this can be traced to the fact that PV experienced radical cost reductions and technical advancements over the previous decade, according to Feldman et al. [8]. In SA, the bid tariff for PV decreased more than three-quarters (75 per cent) from the first to the fourth bid window, and it went as low as $82 \mathrm{c} / \mathrm{kWh}$, as shown in Figure $3 \mathrm{~b}$.

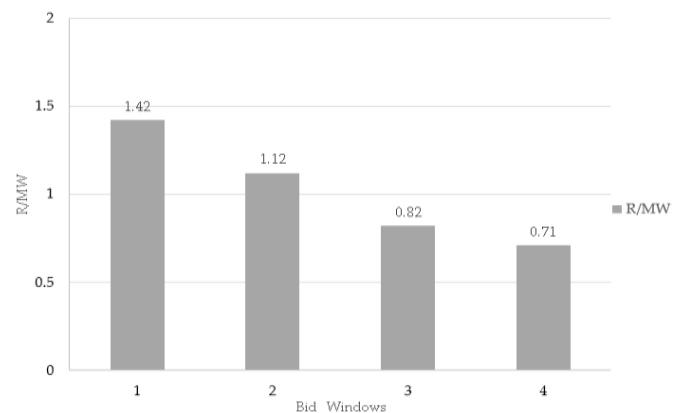

(a)

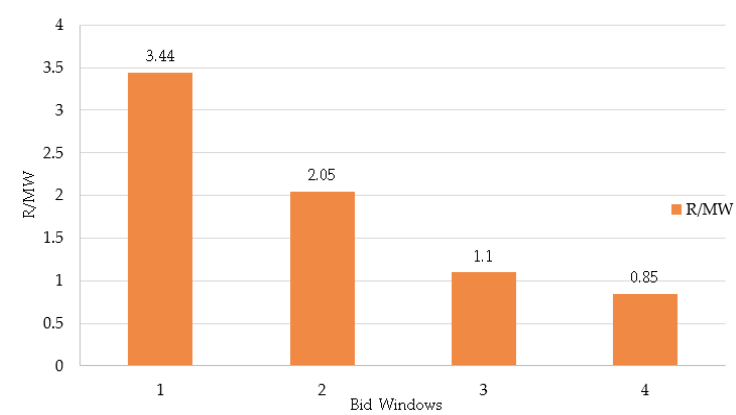

(b)

Figure 3: Average bid price: (a) wind energy, (b) solar PV [1]

\subsection{CSP technology in South Africa}

Viebahn et al. [10] describe CSP as a RET with significant potential to meet part of the future energy demand. Concentrating solar power (CSP) systems are based on the conventional principles of driving 
a turbine and generator for electricity generation. The only difference, however, is the way steam is created; here, sunlight is concentrated using reflecting materials (mirrors) on a receiver to generate heat energy, and the heat is then used to create steam [9]. For example, in the CSP system configuration in Figure 4, the sun is focused on a receiver tube, and the heat generated is used to drive a turbine. The first successfully operated CSP plant was installed in California in the mid-1980s [9], making CSP a young technology (in comparison with other power generation technologies) with many on-going innovations, as well as research and development (R\&D) [11].

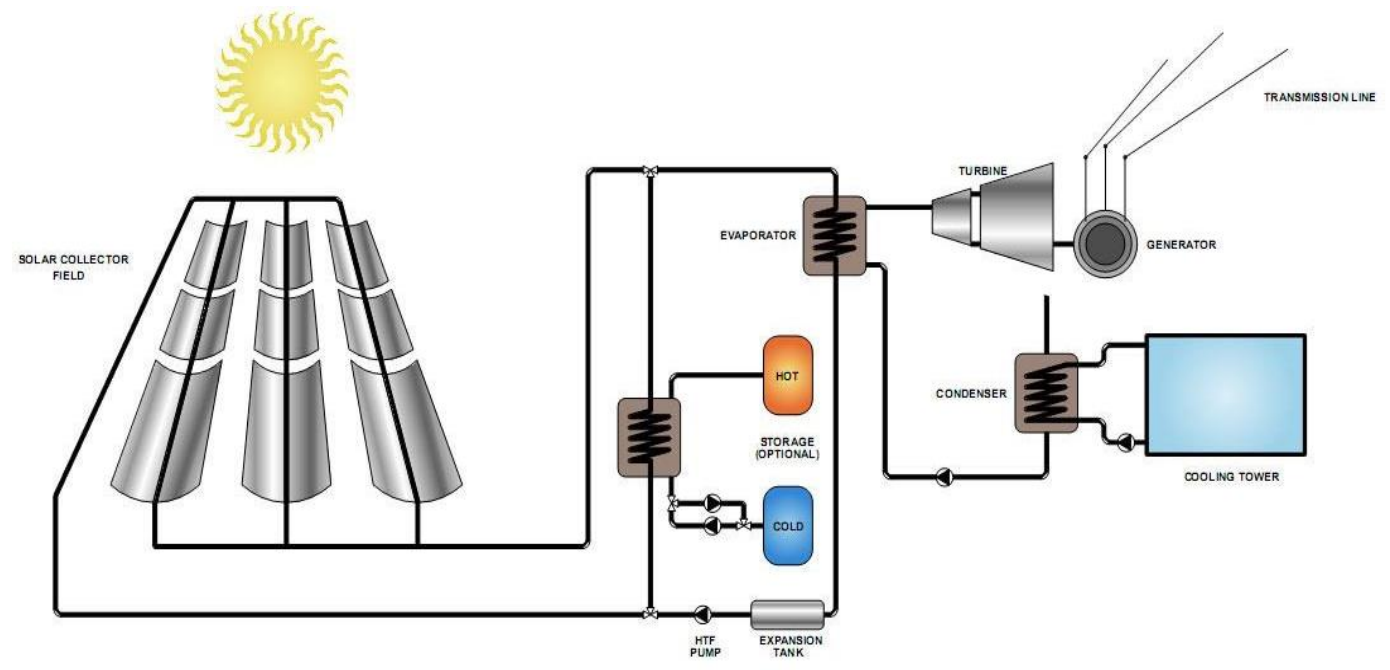

Figure 4: Operation cycle of a CSP plant

When compared with other RETs, the tariff cost of CSP is relatively high; and this fact has slowed down its adoption globally [12]. However, CSP has a unique advantage: it generates high heat energy, and thus offers the option of thermal energy storage. This unique characteristic makes it possible for CSP to be flexible about when and how electricity can be supplied from it throughout a day; and this value is important to the renewable energy portfolio [1]. In order to encourage the competitiveness of CSP in the REIPPPP, the national DoE introduced a special two-tier tariff plan during bid windows 3 and 3.5. The two-tier tariff divided the initial single tariff plan into a base rate and a peak hour rate. The cost of electricity increases by around 270 per cent of the base rate during peak hours [13]. This decision produced a positive result, as the single base rate during the first and second bid windows reduced by about six per cent, and later reduced by up to seven per cent from bid windows 3 and 4, as shown in Figure 5. (Note that bid window 3.5 was exclusive to CSP to encourage the two-tier tariff.) At the end of bid window 3.5, only 50 per cent of the rolled-out bids of CSP had been procured, while wind energy procurement had exceeded its forecast. Solar PV is only $500 \mathrm{MW}$ short of the DoE RET vision 2020.

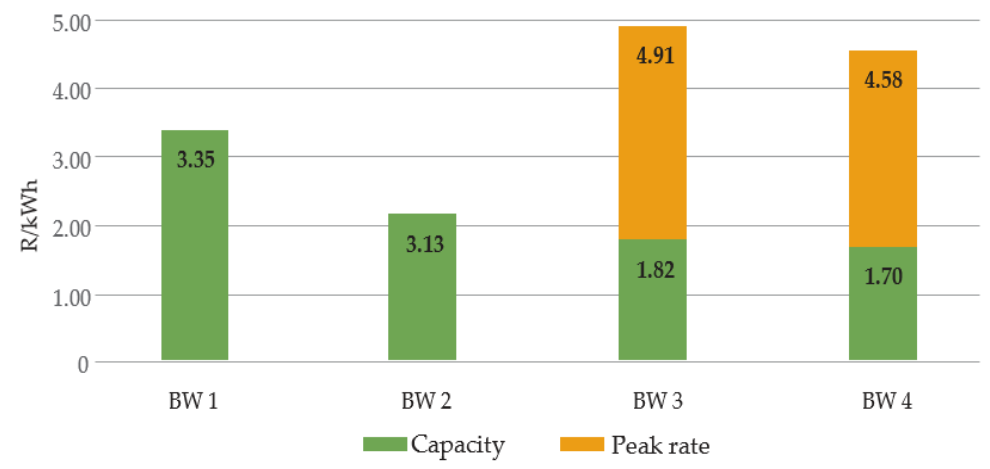

Figure 5: Average bid price for CSP for bid windows [1]

From the four sets of bid windows rolled out in the REIPPPP, the installed capacity of CSP in SA is currently $600 \mathrm{MW}$ [1]; the locations of the plants are shown in the Appendix. The Khi, KaXU, and 
Bokpoort plants are connected to the national grid. Xina, Kathu, and Ilangalethu 1 are under construction, and the Redstone plant is under development. The payback or tariff periods are also shown in the Appendix.

\subsection{Adapted innovation process for CSP in South Africa}

Innovations can be viewed with an integrated flow chart developed by Shum and Watanabe [5], as shown in Figure 6. They considered a system/technology as an end-to-end process, rather than focusing on individual parts. This makes it easy to identify both the weakest and the strongest links in a technology under review. The first stage is idea generation, which begins in-house and grows until good partnerships are formed with other firms. The second stage is the conversion of these ideas into the desired result. The initial innovation gap is crossed here, and the building and the development, as well as improvement, is done at this stage. The final stage is termed the 'diffusion' stage, in which the technology spreads across different organisations. Here, innovation is adopted by other existing systems, and diffuses into the norm, either by using the existing facilities, or by developing a new one.

Analysing the innovation process adopted by companies that won CSP bids in SA and that used this end-to-end process of integrated flow innovation charts shows that CSP technology in SA is at the diffusion stage, because the technologies used by these companies were developed in their home countries; only the spreading of the technologies is seen in SA.

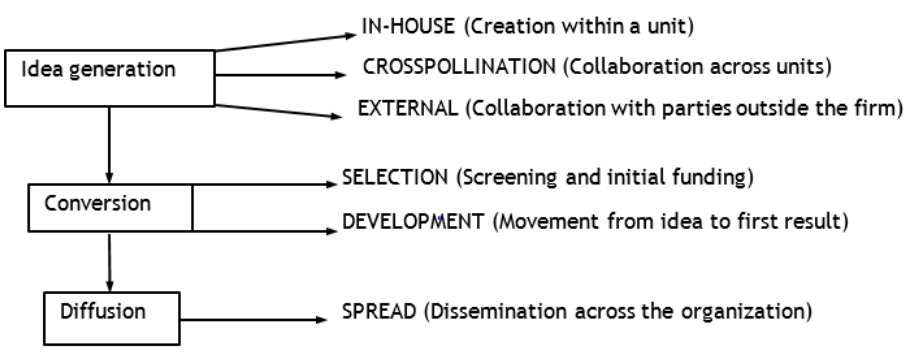

Figure 6: Innovation in a value chain

Abengoa, for example, owns three of the CSP plants; KaXU and Khi are already connected to the national grid, and the company provides the services and maintenance needed for the continuous running of the plants. The company claims to be making efforts to improve on each new plant in order to satisfy the consumers, who are the end-users of the electricity [14]. Due to continuous improvements through R\&D, a systematic R\&D type of innovation process is believed to have been adopted by pioneers of CSP technologies in SA.

\section{IMPACTS AND CHALLENGES OF CSP TECHNOLOGY IN SOUTH AFRICA}

\subsection{Technological impact}

Most of the technological developments carried out by the foreign companies that won the CSP bids in SA were achieved through their own subsidiaries, which are also foreign companies. The demand for local CSP expertise motivated the appearance of some local companies. An example is Ilangalethu Solar Power Pty (Ltd), which is building a CSP plant, Ilangalethu 1, under the supervision of another local company, Emvelo. Other CSP technology needs are now being developed in SA. In addition, GeoSun, a spin-off company from the Centre for Renewable and Sustainable Energy Studies (CRSES) at Stellenbosch University, is involved in solar resource mapping and for instrumentation for CSP plants under construction and during operations. Helio100 is another local setup; it is a $100 \mathrm{~kW}$ CSP research facility of the Solar Thermal Energy Research Group (STERG) at Stellenbosch University, which has been able to manufacture heliostats from locally made materials. The heliostats were built as intelligent, self-calibrating, modular-design systems.

Also, ACWA Power claims that, during the construction of the recently commissioned Bookport CSP plant, materials and components worth well over ZAR 2 billion were purchased from local companies, which shows the increase in development of the CSP market in SA [15]. 
The development of CSP in SA has attracted global interest. SA hosted SolarPaces 2015, the most referred-to academic and industrial conference on CSP technologies in the world. The conference brought together world leaders (in both industry and academia) in CSP technologies, and the local companies were able to meet global leaders in their respective sectors.

\subsection{Socio-economic impact}

When all the CSP plants in SA become operational, they will together eliminate an annual carbon emission in excess of 1.3 million tonnes; and it is estimated that 563,000 households in SA will have access to a clean energy supply. The existing CSP plants, together with the new ones to be built, will contribute immensely to the DoE vision for the year 2030, which is the desire to generate 17,800 MW of the total SA electricity from renewable energy sources [1]. Around 10,000 jobs, from construction through to the operations of the plants, will be created, both temporary and permanent. In addition, Abengoa Solar and ACWA Power have started development activities, including youth empowerment through small- and medium-scale entrepreneurship support, in the local communities that are hosts to their CSP plants. Also, the presence of CSP plants has opened these communities to industrialisation, new markets, and new business opportunities [14], [15].

CSP systems attain very high temperatures during operations [16], and require water for cooling, especially when the system is not dry-cooled. Most of the CSP plants are in the Northern Cape Province, where there is a shortage of water; therefore, the water requirements and consumption of CSP can create more drought pressures in the region. This impact was considered in some of the plants' design. Khi, for example, uses an air-cooled technology to reduce water usage by two-thirds. However, other plants require water for cooling and thus, if not properly managed, could affect the available water in the host communities.

\subsection{CSP challenges}

The challenges faced by CSP technologies can be summed up as having three aspects: cost and funding, market and political will, and technology. Using the example of KaXU Solar One, which is connected to the grid, the following challenges are identified:

\subsubsection{Cost and funding}

There is wide gap between the design stage and the manufacturing stage of RETs, as identified by Tsoutsos and Stamboulis [4]. One of the causes of this gap is the expensive nature of RETs. In addition, funding has been a major constraint on the deployment of all types of RETs; the quality of manufactured systems is sometimes compromised by the low availability of funds, or by expensive raw materials, thus making it less attractive, and often having only limited applications [17]. This makes the relevant decision-makers less interested in adopting basic renewable energy research outputs, and thus limits its diffusion into industries. The overall adoption of RETs innovations has been slow, mainly because of these constraints.

Private financial institutions rarely support developing technologies: they have not been tested over time because they are often capital-intensive, and investment is seen as a high risk. This makes accessing clean technology loans from the World Bank difficult for local companies, because of their lack of experience in CSP technology, and the risk associated with the investment. KaXU Solar One had a capital investment of about USD 890 million, and Khi Solar One was estimated at USD 445 million [18]. To cover these estimated costs, Abengoa Solar, the Industrial Development Corporation (IDC), and the local SA Community Trust Fund formed a consortium, in which Abengoa Solar (a foreign company with much experience) held the majority of the shares. This consortium was able to leverage loans of USD 160 million and USD 30 million from the World Bank's International Finance Corporation (IFC) for the KaXU and Khi plants respectively [19]. This amount was around 12 per cent of the total capital investment, which meant that the consortium had to come up with the remaining funding by other means.

\subsubsection{Market and political will}

Electricity is the same, regardless of how it is generated. However, the cost of electricity per kWh differs according to the various methods of generation. The average current price of electricity from Eskom, SA's utility company, is ZAR 1.2/kWh (about USD $8 \mathrm{c} / \mathrm{kWh}$ [20]), while the cost of electricity generated by KaXU is ZAR 2.69/kWh (USD $22 \mathrm{c} / \mathrm{kWh}$ [13]). This shows that, even though the energy generated is clean, the price is high. This is a major challenge, as the technology might not be successful if the government were not committed to the advancement of RETs. KaXU Solar One was connected to the national grid in early 2015, and has since been sustained through government subsidy. 
As discussed above, the DoE, through the REIPPPP, introduced a two-tier tariff plan - base and peak periods - in bid windows 3 and beyond. Bid window 3.5 was won by a consortium formed by Solar Reserve (a United States-based company) and ACWA Power (a Saudi Arabian company) to build the Redstone plant. This project is currently under development, and will use the two-tier tariff plan. The electricity cost will be USD $14 \mathrm{c} / \mathrm{kWh}($ ZAR $1.65 / \mathrm{kWh})$ for the base price, rising by up to 270 per cent in peak periods. Zero cost will be charged for the energy supplied between 10:30 pm and 5:00 am [13].

\subsubsection{Technological challenges}

The CSP technologies are high-tech innovations, and need various levels of technology transfer for a company to begin production. In SA, the existing CSP plants were largely built by foreign companies, most of which are experienced in the sector and have running plants around the globe. For example, Khi Solar One was the first Abengoa Solar tower system outside Spain; but it is simply a replica of those plants. Despite the ongoing research in the National System of Innovation (see section 3.1), very few local industries are involved in CSP technology in SA.

CSP technologies also have limited storage capability [11]; and increasing the storage capacities of the plants will increase the utility price per kWh [14]. There is a need, therefore, for more research into storage techniques that will be less expensive and more effective.

\subsection{4 'Valley of death' (VoD) faced by spin-off companies}

The 'valley of death' $(\mathrm{VoD})$, in this context, is when a demonstrated technology cannot reach the market because of it is unable to scale up through the commercialisation phase. This occurs when an innovator of a technology has shown that the technology is viable and realistic, but cannot obtain the resources needed for mass production or scale-up of the product or technology.

Some of the CSP technology resources and component designs have now been developed by local companies, as discussed in section 3.1. The strength of new research facilities like Helio100 is yet to be confirmed, as they have only recently started. Although they have great potential, their innovations are yet to cross the VoD of technology adoption.

Some barriers faced by young developing companies, such the ones involved in CSP in SA, limit the commercialisation of their technologies. These were identified by Frank et al. [21], and confirmed by Bosetti et al. [22]:

- $\quad$ the tedious process involved in contracting/procurement;

- $\quad$ potential liability exposure for developers;

- $\quad$ the inability to transfer technological development into technology deployment efforts; and

- insufficient fund to acquire state-of-the-art technology, and also limited available cost data.

A major challenge faced by CSP that reduces its adoption is its limited scalability. CSP is more efficient on large scales, but it is almost impossible to use on very small scales, as, for example, in off-grid applications. The rapid cost cuts experienced by solar PV are a result of PV's scalability that is, its ability to supply energy cheaply in simple units. Bosetti et al. [22] identified that solar energy, despite the belief that it is the energy solution of the future, will continue to be more expensive than fossil fuels, unless tougher legislation, in terms of tax and other policies is passed on the use of hydrocarbons. Other non-technical barriers that also affect the diffusion of CSP technologies are unfavourable power pricing rules and ad hoc policy interventions, an example of which is feed-in tariffs. [22]. Despite the readiness of SA to fund RETs, there is a significant reluctance to fund technologies like CSP that have not been domestically proven over time. Some of the reasons for the limitations faced by CSP in SA were presented in a SAGEN report [23]:

- $\quad$ local R\&D in CSP seems to be under-funded;

- local companies are unable to compete with international companies in labour cost and productivity;

- $\quad$ it is difficult to secure funding assistance because financial institutions tend to favour more accepted and proven technologies (e.g., solar PV) over a younger technology like CSP;

- the future cost reduction of competing renewable energy methods might occur faster than with CSP;

- $\quad$ transportation of imported materials from the ports to the CSP plants is expensive; and 
- $\quad$ CSP requires high water usage, and the shortage of water supply in SA might discourage CSP growth.

The above challenges make it difficult to maximise the global advancement in CSP technology in SA, and they also hinder the diffusion of the technologies developed, especially by small research groups and their sister spin-off companies, and thus prevent the innovations from crossing the VoDs.

The next section presents how some players in South Africa have approached the challenge of overcoming the identified limitations to massive deployment of CSP in the country.

\section{THE DYNAMIC ROLES OF ORGANISATIONS, UNIVERSITIES, AND GOVERNMENT IN THE CSP INDUSTRY}

Universities and organisations such as industries and institutes conduct innovative research into CSP. There is the possibility of a higher degree of interaction when these stakeholders work together. This interaction had been successful in various scenarios in the past, because technology champions are carried along throughout the innovation process in this research approach [24].

The roles of each of the stakeholders in the cycle of innovation were defined by Bozeman [25] as complementary, not competing, in his market failure technology paradigm. The role of government is to break the market barrier for innovations by enacting favourable laws, regulations, free trade agreements, and neutral impact taxation. Universities are the knowledge providers, educators, and suppliers of public domain research, while industries (although they prefer to keep their innovations secret from competitors) can work together with the universities and government in this cycle for better results.

In SA, strategies to cross the CSP technology VoD have generally been deployed with other renewable energy systems (which can be a limiting factor, as each type of renewable energy has its own challenges). Various agencies and government entities have been set up to fund, direct, regulate, or actively participate in the R\&D of RETs in SA. Three of these organisations are discussed in the sections below; their roles in the development and deployment of RETs are presented; and an overview of the impact on the economy is highlighted.

\subsection{National Research Foundation (NRF)}

The National Research Foundation (NRF) is a SA government body that is responsible for promoting and supporting research through funding. The NRF also facilitates the creation of knowledge and innovation that improves the quality of life of South Africans. Table 1 shows the 2014/2015 annual report of this organisation and the various programmes it funded, with their impact on the South African economy.

Table 1: NRF statement of financial performance for non-exchange transactions [26]

\begin{tabular}{|c|c|c|c|}
\hline & & 2015 & 2014 \\
\hline & & $\mathrm{R}^{\prime} 000$ & $\mathrm{R}^{\prime} 000$ \\
\hline Programme 1 & Corporate & 67249 & 64028 \\
\hline Programme 2 & $\begin{array}{l}\text { Science Engagement } \\
\text { Research and Innovation Support and }\end{array}$ & 134756 & 129015 \\
\hline Programme 3 & $\begin{array}{l}\text { Advancement } \\
\text { Nuclear, Biodiversity, Environmental \& }\end{array}$ & 1877163 & 1930890 \\
\hline Programme 4 & $\begin{array}{l}\text { Conservation Sciences } \\
\text { National Research Facilities of Astro- }\end{array}$ & 378005 & 342852 \\
\hline Programme 5 & Geosciences & 359706 & 303398 \\
\hline Total expenditure & & 2816879 & 2770183 \\
\hline
\end{tabular}

Through its 'Programme 3' - Research and Innovation Support Advancement (RISA) - the NRF collaborates with industrial stakeholders to champion the shift to RETs. The funds available for this programme were channelled in two ways: through the Energy Human Capacity Development and Knowledge Generation (EHCD\&KG) programme; and through the Centre for Renewable and Sustainable Energy Studies at Stellenbosch University (SU). 
- $\quad$ The Energy Human Capacity Development and Knowledge Generation (EHCD\&KG) programme: This is a consortium of several programmes and funding boards that include the South African Nuclear, Human Asset and Research Programme (SANHARP); the Renewable and Sustainable Energy Scholarships (RSES); the Masters in Accelerator and Nuclear Science (MANUS); the Masters in Material Science (MatSci); and the Doctoral Studies in Energy Efficiency (DSEE).

- The Centre for Renewable and Sustainable Energy Studies at SU: This is the hub of renewable and sustainable energy research in South African universities. It comprises several spokes, including the wind energy research group, hosted by SU and the University of Cape Town; the solar thermal energy research group (STERG), hosted by SU and the University of Pretoria; and the Solar Photovoltaic research groups, which have their base at the University of Fort Hare and Nelson Mandela Metropolitan University.

In this way, the NRF has been able to use an inclusive model in which all the stakeholders in the renewable energy sector of SA - experts and academics alike - work together to achieve the goal of RET advancement in SA.

\subsection{SANEDI tax incentives}

Tax incentives have been identified as a major impact factor in accelerating the deployment of renewable energies [27]. SA recently reviewed its tariff law under Income Tax Act No. 58 of 1962, with a new regulation published by the Minister of Finance under section $12 \mathrm{~L}(5)$ in Government Notice No. 10080 (Government Gazette No. 37136 of 9 December 2013), and amended by Government Notice No. R.186 (Government Gazette No. 38541 of 6 March 2015) [28]. The South African National Energy Development Institute (SANEDI), a state-owned entity, was formed as a result of this regulation. SANEDI was given the responsibility to issue certificates and coordinate tax returns for equivalent hours of energy saved. SANEDI has facilitated the increased deduction of the kilowatt hours equivalent of energy saved from 45 to 95 cents per kilowatt hour as tax incentives. This has been in effect since 1 March 2015 [28].

The tax incentive is the amount paid to organisations or individuals that produce renewable electricity. It is often used to motivate more efficient energy usage and the development of more privately owned renewable energies. However, using the same base or standard tax incentive for all RETs is often not effective [29]. Shum [29] reported that tax incentives can only be effective and lead to a rapid RET diffusion if the rate is scientifically calculated and differentiated for each type and size of RET. In the United States, for example, the tax credit rebate for RETs varies depending on the type of operation, size, and capacity [30]. They conveniently separated the tax incentives based on size into either residential or industrial [30].

\subsection{Renewable Energy Independent Power Producer Procurement Programme (REIPPPP)}

The REIPPPP, an extension of the SA Department of Energy (DoE), has overseen the investment of over 168 billion Rands by various companies in the development of RETs in SA [1]. It has rolled out four rounds of bid windows since 2011. This has led to the allocation of 79 different renewable energy projects nationwide with a total power capability of $6000 \mathrm{MW}$. The majority of these projects are concentrating solar power (CSP) plants, solar photovoltaic, and onshore wind technologies. REIPPPP also regulates the electricity tariffs using various innovative methods. For example, REIPPPP currently regulates the two-tier tariff payment options for CSP, discussed in section 2.1.

\section{AN EVOLVING RESEARCH ENVIRONMENT}

With the level of interest shown by the South African government in RETs development, there is a need for each type of RET to be analysed and developed as an individual entity in order to maximise its potential. As discussed before, CSP is a young technology, and only limited literature is available on the analysis of its feed-in tariffs, deployment, dispatchability, off-grid installation, and adoption.

In the literature, several technology adoption/diffusion models have been developed for solar PV by Shum [5], [6], [29], and for other renewable energy sources by Breukers [31], Wüstenhagen [32], and Zoellner [33]; but there has been limited work in this field for CSP. Technology diffusion or adoption is an important part of the cycle chain of invention-innovation-diffusion. Shum [29] identified the direct link between innovation characteristics and technology diffusion, to make it 
necessary to adapt the available adoption models to the technology of interest, or to develop a new technology adoption model for it.

\subsection{Technology adoption review}

Various studies are available in the literature that address innovations, technology transfer, and diffusion. (See Amesse and Cohendet [34] and Bozeman [25] for a general discussion on diffusion and deployment of technologies.) The roles of different stakeholders and intermediaries in facilitating the processes of technology transfer and deployment are also presented by Lane [35].

\subsubsection{Technology adoption studies}

Coughlan et al. [36] classified technology adoption models in the literature into five groups, based on the modalities and dimensions that were followed in building the models. The classification models include industry-based, interest-based, type-of-innovation-based, analysis-approach-based, and models based on the stage of the technology in the technology adoption life (TAL) cycle.

Technology adoption models have been used to study various technology and market trends in the literature. These include computers, electric cars, pharmaceutical drugs, television, camera, consumer goods, and PV. These analyses have also been used to study major technological incidents and other occurrences such as HIV/AIDS [37], [38]. The literature groups by Coughlan et al. [36] view technology adoption as a diffusion process involving the five stages of awareness, interest, evaluation, trial, and adoption; and this corresponds with the TAL curve developed by Moore [39], as shown in Figure 12. Moore classified innovation adopters as innovators, early adopters, early majority, late majority, and laggards.

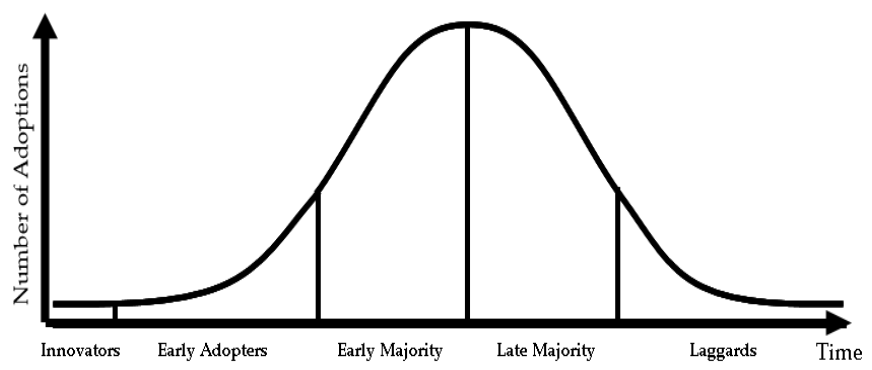

Figure 7: Technology adoption lifecycle [39]

If the global sustainable development goals are to be achieved, the diffusion of environmentally friendly technologies should be encouraged [40]. Despite the support of government, and its obvious advantages, RETs adoption is still slow; thus, developing adoption strategies for them is vital. However, the challenge in using the conventional methods of adoption listed above for RETs is that, as opposed to other matured and independent technologies, RETs currently thrive on government incentives and support policies, as well as on the global desire to combat climate change [40].

\subsection{Existing adoption/diffusion frameworks}

Technology adoption/diffusion is core to the cycle of invention, innovation, and diffusion, and it is a determining factor for the survival of technical changes or new products [41]. Some inherent characteristics of innovation have been identified by Rogers [41] as affecting technology adoption: its relative advantages, compatibility, and reduced complexities compared with the existing ones. A detailed analysis of the diffusion of RETs, as related to these characteristics, was presented by Jacobsson and Johnson [42].

There are two methods to analyse the pattern of technology adoption, as identified by Geroski [43] and later confirmed by Shum [29]: the epidemic method, and the choice or equilibrium approach.

\subsubsection{Epidemic approach}

This is the earliest, most popular, and most widely used analytical approach in studying diffusion patterns. Here, the potential adopters of technology are assumed to be homogenous [29], and information about a new product or innovation is disseminated through one-on-one interactions, or based on current or potential adopters' location proximities. This model encourages direct marketing through the communication of the economic and technical advantages of the technology 
to the end-users or adopters. The drawback of this approach is that it assumes that the adopters have the same intended use for the innovation, or that potential adopters have the same needs.

\subsubsection{Equilibrium or choice approach}

Unlike the assumption of adopter homogeneity in the epidemic approach, this approach assumes that potential adopters are heterogeneous in nature. Here, adopters are believed to have different values for costs and needs, and that technology adoption is only favoured when certain minimum expectations of each adopter are met. The spread of the minimum values, or the differences in the minimum values of adopters, are used to analyse the rate of technology adoption [29]. This method proves that interested adopters will not all adopt an innovation at the same time, and that adoption rates can only be rapid when a greater level of similar potential adopters' minimum values has been met. This is useful in analysing the diffusion of complex technologies in which the innovation values might be hard to measure or communicated perfectly. CSP is such an example.

\section{CONCLUDING REMARKS}

The adoption of CSP in SA is having major positive effects on the supply of clean electricity. When all six CSP plants discussed in this paper are in full operation, 1.5 million tonnes of carbon emission will be prevented annually. The identified CSP consortiums are carrying out competence-enhancing activities, as the companies have to train the newly employed operators, thus leading to local competence and skills development programmes.

The innovation analysis carried out on CSP technologies in SA also shows that its tariff is currently higher than that of other major RETs (wind and PV), and that the innovation experience of South African CSP technology is incremental, as each subsequent plant was an improvement on previous facilities elsewhere. The development of research into innovation, and eventually into market products of CSP systems, is improving with a closer relationship and working together of the stakeholders. This progress, however, is slow, because of the limited knowledge in identifying and understanding the important activities and policy instruments that can aid the prioritisation of important actions to forge better relationships among stakeholders and fast track the deployment of CSP.

Some research facilities have been built to improve the technical R\&D knowledge of CSP, while some independent and spin-off companies have begun operations in CSP technologies. The government has shown much interest by prioritising CSP, and the efforts towards its deployment are presented in this paper.

The first step to having a detailed adoption framework for CSP in SA is to develop a comprehensive roadmap. There is an existing roadmap for the advancement of solar energy in SA [44], in which all the solar energy technologies in SA were harmonised as far as possible and treated as one. However, each solar technology faces specific technological and economic challenges, market dynamics, and deployment limitations, thus suggesting the need for roadmaps with high technical and economic specificity for CSP.

The two-tier tariff plans introduced by REIPPPP have reduced CSP tariffs up to seven per cent [13]. This attempt to support CSP adoption in SA is based on a dispatchability tariff plan [45]-[47]; however, the development of technology adoption frameworks and models for other RETs such as PV have resulted in a reduction of over 75 per cent. It is therefore pertinent to develop a working adoption model that can inform policy-makers of the right decisions to increase the uptake of CSP in SA.

\section{RECOMMENDATIONS}

Since there is little or no literature available on CSP technology adoption and deployment models, this study recommends that an appropriate technology adoption/diffusion model, which could incorporate the joint effects of learning and the necessary network externalities involved in CSP usage, be developed. This will allow for easy diffusion of the technology into the economy. The first step towards success in CSP deployment, therefore, is to develop a technology-specific roadmap that focuses on CSP technology alone. The next step is to identify the most important factors limiting CSP technology adoption in SA. These factors would be the basis on which an adoption model could be built, and would suggest the framework that could serve as policy instruments for decision-makers on the best choices for deployment strategies for CSP technology. 
Finally, it is important for the DoE to encourage localisation of the CSP technology, as this will boost the ability to maximise profit in the CSP innovation cycle. This will also allow local companies to access the technology development ideas, technology know-how, and transfer, and then to develop new processes and perform independent R\&D.

\section{REFERENCES}

[1] DoE. 2015. State of renewable energy in South Africa. Department of Energy Annual Report.

[2] Fluri, T.P. 2009. The potential of concentrating solar power in South Africa. Energy Policy, 37(12), pp. 5075-5080.

[3] SolarGIS. 2011. Poster maps (wall maps) for solar energy [Online]. Available: http://solargis.info/doc/po stermaps [Accessed: 15 February 2014].

[4] Tsoutsos, T.D. \& Stamboulis, Y.A. 2005. The sustainable diffusion of renewable energy technologies as an example of an innovation-focused policy. Technovation, 5(7), pp. 753-761.

[5] Shum, K.L. \& Watanabe, C. 2007. Photovoltaic deployment strategy in Japan and the USA - An institutional appraisal. Energy Policy, 35(2), pp. 1186-1195.

[6] Shum, K.L. \& Watanabe, C. 2008. Towards a local learning (innovation) model of solar photovoltaic deployment. Energy Policy, 36(2), pp. 508-521.

[7] Ibenholt, K. 2002. Explaining learning curves for wind power. Energy Policy, 30(13), pp. 1181-1189.

[8] Feldman, D., Barbose, G., Margolis, R., Wiser, R., Darghouth, N. \& Goodrich, A. 2012. Photovoltaic (PV) pricing trends: Historical, recent, and near-term projections. NREL-DOE Tech. Rep., November, pp. 1-30.

[9] Kalogirou, S.A. 2009. Solar energy engineering processes and systems, $1^{\text {st }}$ ed. London: Academic Press Elsevier.

[10] Viebahn, P., Lechon, Y. \& Trieb, F. 2011. The potential role of concentrated solar power (CSP) in Africa and Europe - A dynamic assessment of technology development, cost development and life cycle inventories until 2050. Energy Policy, 39(8), pp. 4420-4430.

[11] Stine, W.B. \& Geyer, M. 2001. Power from the sun [Online]. Available: Power from the sun.net. http://www.powerfromthesun.net/book.html [Accessed: 15 February 2014].

[12] IEA. 2010. IEA world energy outlook report. 75739 Paris Cedex 15.

[13] CSP Today Markets Reports - South Africa. 2015. CSP today markets reports series, An Industry overview - South Africa. London.

[14] Abengoa Solar. 2014. Solar power for a sustainable world [Online]. Available: http://www.abengoasolar.com/web/en/plantas_solares/plantas_propias/sudafrica/\#seccion_1 [Accessed: 24 February 2016].

[15] ACWA Power. 2016. Bokpoort concentrated solar plant inaugurated [Online]. Available: http://energy.org.za/news/bokpoort-concentrated-solar-plant-inaugurated/ [Accessed: 26 April 2016].

[16] Harris, J.A. \& Lenz, T.G. 1985. Thermal performance of solar concentrator/cavity receiver systems. Sol. Energy, 34(2), pp. 135-142.

[17] Tödtling, F. \& Trippl, M. 2005. One size fits all? Res. Policy, 34(8), pp. 1203-1219.

[18] Abengoa CSP SA. 2010. Summary of proposed investment by Abengoa Solar for IFC. [Online]. Available: http://ifcext.ifc.org/ifcext/spiwebsite1.nsf/Docs [Accessed: 25 February 2015].

[19] CSP-World. 2012. IFC (World Bank) disclose the summary of proposed investment for Abengoa's South Africa CSP plants [Online]. Available: http: / /www.csp-world.com/news/20120430/00194/ifc-world-bankdisclose-summary-proposed-investment-abengoa-s-south-africa-csp [Accessed: 12 February 2016].

[20] Eskom. 2014. What is load shedding? [Online]. Available: http: / /loadshedding.eskom.co.za/loadshedding/description [Accessed: 20 July 2015].

[21] Frank, C., Sink, C., Mynatt, L., Rogers, R. \& Rappazzo, A. 1996. Surviving 'Valley of Death': A comparative analysis. Technol. Transf., 21(1), pp. 61-69.

[22] Bosetti, V., Catenacci M., Fiorese, G. \& Verdolini, E. 2012. The future prospect of PV and CSP solar technologies: An expert elicitation survey. Energy Policy, 49, pp. 308-317.

[23] SAGEN. 2013. Assessment of the localisation, industrialisation and job creation potential of CSP infrastructure projects in South Africa - A 2030 vision for CSP. Johannesburg.

[24] Etzkowitz, H. \& Leydesdorff, L. 2000. The dynamics of innovation: from national systems and 'Mode 2' to a triple helix of university-industry-government relations. Res. Policy, 29(2), pp. 109-123.

[25] Bozeman, B. 2000. Technology transfer and public policy: A review of research and theory. Res. Policy, 29(4-5), pp. 627-655.

[26] NRF Reports. 2015. National Research Foundation annual report 2014-2015. Pretoria.

[27] Mendonca, M. 2007. Feed-in tariffs. Accelerating the Deployment of Renewable Energy. Earthscan Routledge.

[28] SANEDI Media Reports. 2016. South African National Energy Development Institute media release. Johannesburg.

[29] Shum, K.L. 2013. A general technology adoption model of solar photovoltaic under feed-in tariff policy incorporating learning and network effects. J. Renew. Sustain. Energy, 5(4), p. 043128.

[30] Energy.gov. 2015. Renewable energy tax credits. United States Internal Revenue Service [Online]. Available: http://www.energystar.gov/taxcredits [Accessed: 16 March 2016]. 
[31] Breukers S. and Wolsink, M. 2007. Wind power implementation in changing institutional landscapes: An international comparison. Energy Policy, 35(5), pp. 2737-2750.

[32] Wüstenhagen, R., Wolsink, M. \& Bürer, M.J. 2007. Social acceptance of renewable energy innovation: An introduction to the concept. Energy Policy, 35(5), pp. 2683-2691.

[33] Zoellner, J., Schweizer-Ries, P. \& Wemheuer, C. 2008. Public acceptance of renewable energies: Results from case studies in Germany. Energy Policy, 36(11), pp. 4136-4141.

[34] Amesse, F. \& Cohendet, P. 2001. Technology transfer revisited from the perspective of the knowledgebased economy. Res. Policy, 30(9), pp. 1459-1478.

[35] Lane, J.P. 1999. Understanding technology transfer. Assist. Technol., 11(1), pp. 5-19.

[36] Coughlan, P., Dew, N. \& Gates, W. 2008. Crossing the technology adoption chasm: Implications for DoD. Dudley Knox Library, Naval Post Grad. Schl. Monterey, CA.

[37] Fisher, J.C. \& Pry, R.H. 1971. A simple substitution model of technological change. Technol. Forecast. Soc. Change, 3, pp. 75-88.

[38] Meade, N. \& Islam, T. 1998. Technological forecasting - Model selection, model stability, and combining models. Manage. Sci., 44(8), pp. 1115-1130.

[39] Moore, G. 1991. Crossing the chasm: Marketing and selling high-tech products to mainstream consumers. New York, NY: HarperBusiness.

[40] Rao, K.U. \& Kishore, V.V.N. 2010. A review of technology diffusion models with special reference to renewable energy technologies. Renew. Sustain. Energy Rev., 14(3), pp. 1070-1078.

[41] Rogers, E.M. 1995. Diffusion of innovations, $4^{\text {th }}$ ed. New York: Free Press.

[42] Jacobsson, S. \& Johnson, A. 2000. The diffusion of renewable energy technology: An analytical framework and key issues for research. Energy Policy, 28(9), pp. 625-640.

[43] Geroski, P. 2000. Models of technology diffusion. Res. Policy, 29(4-5), pp. 603-625.

[44] Brent, A.C. 2015. Solar energy RDI roadmap for South Africa. Third Southern African Solar Energy Conference, Kruger Park, South Africa. pp. 48-53.

[45] Gauché, P., Pfenninger, S., Meyer, A.J., Von Backström, T.W. \& Brent, A.C. 2012. Modelling dispatchability potential of CSP in South Africa. Southern African Solar Energy Conference (SASEC), 1, pp. 1-11.

[46] Silinga, C., Gauché, P., Rudman, J. \& Cebecauer, T. 2015. The South African REIPPP two-tier CSP tariff: Implications for a proposed hybrid CSP peaking system. Energy Procedia, 69, pp. 1431-1440.

[47] Gauché, P., Von Backström, T.W. \& Brent, A.C. 2011. CSP modeling for macro decision making - Emphasis on the central receiver type. SolarPACES Conference, Granada, Spain. [Online]. Available: http://blogs.sun.ac.za/sterg/files/2011/08/SolarPACES2011_Gauche_final.pdf [Accessed: 1 March 2016] 
APPENDIX: DETAILS OF CSP PLANTS IN SOUTH AFRICA

\begin{tabular}{|c|c|c|c|c|c|c|c|c|c|c|c|c|c|}
\hline $\begin{array}{c}\text { Window } \\
\text { no }\end{array}$ & Name & Technology & Location & Capacity & $\begin{array}{c}\text { Storage } \\
\text { capacity } \\
\text { (hrs) }\end{array}$ & Owners & $\begin{array}{c}\text { Solar } \\
\text { field } \\
\text { size } \\
\left(\mathrm{km}^{2}\right)\end{array}$ & $\begin{array}{c}\text { Cost } \\
\text { (USD } \\
\text { million) }\end{array}$ & $\begin{array}{c}\text { PPA/Tariff } \\
\text { period or } \\
\text { rate }\end{array}$ & $\begin{array}{l}\text { Total } \\
\text { jobs }\end{array}$ & $\begin{array}{c}\text { No of } \\
\text { household } \\
\text { covered }\end{array}$ & $\begin{array}{c}\text { Carbon } \\
\text { emission } \\
\text { prevented/yr }\end{array}$ & $\begin{array}{l}\text { Start } \\
\text { year }\end{array}$ \\
\hline \multirow[t]{2}{*}{1} & KaXU & trough & Pofadder & $100 \mathrm{MW}$ & 2.5 & $\begin{array}{l}\text { Abengoa, IDC, } \\
\text { KaXU } \\
\text { community } \\
\text { trust }\end{array}$ & 0.8 & 860 & $20 \mathrm{yrs}$ & 1000 & 80,000 & 300,000 & 2015 \\
\hline & Khi & tower & Upington & $50 \mathrm{MW}$ & 2 & $\begin{array}{l}\text { Abengoa, IDC, } \\
\text { Khi } \\
\text { community } \\
\text { trust }\end{array}$ & 0.6 & 376 & 20 yrs & 600 & 45,000 & 183,000 & 2016 \\
\hline 2 & Bokpoort & trough & Groblershoop & $50 \mathrm{MW}$ & 9.3 & $\begin{array}{l}\text { ACWA Power, } \\
\text { Solafrica } \\
\text { Bokpoort CSP } \\
\text { Power Plant } \\
\text { (Pty) Ltd }\end{array}$ & 0.6 & 565 & $20 \mathrm{yrs}$ & 1300 & 200,000 & $\mathrm{n} / \mathrm{a}$ & 2016 \\
\hline \multirow[t]{2}{*}{3} & Xina & trough & Pofadder & $100 \mathrm{MW}$ & 5 & $\begin{array}{l}\text { Abengoa, IDC, } \\
\text { PIC, KaXU } \\
\text { community } \\
\text { trust }\end{array}$ & 0.6 & 880 & 20 yrs & 1,300 & 90,000 & 398,000 & 2017 \\
\hline & Ilanga 1 & trough & Upington & $100 \mathrm{MW}$ & 4.5 & Emvelo, Cobra & $\mathrm{n} / \mathrm{a}$ & 972 & $20 \mathrm{yrs}$ & $\mathrm{n} / \mathrm{a}$ & $\mathrm{n} / \mathrm{a}$ & $\mathrm{n} / \mathrm{a}$ & 2017 \\
\hline \multirow[t]{2}{*}{3.5} & $\begin{array}{l}\text { Kathu } \\
\text { solar } \\
\text { park }\end{array}$ & trough & Kathu & $100 \mathrm{MW}$ & & $\begin{array}{l}\text { Kathu Solar } \\
\text { Park } \\
\text { Consortium }\end{array}$ & $\mathrm{n} / \mathrm{a}$ & $\mathrm{n} / \mathrm{a}$ & 20 yrs & 1200 & 80,000 & 300,000 & 2018 \\
\hline & Redstone & tower & Postmasburg & $100 \mathrm{MW}$ & 12 & $\begin{array}{l}\text { ACWA, Solar } \\
\text { reserve }\end{array}$ & $\mathrm{n} / \mathrm{a}$ & 715 & \$124/MWh & 4000 & 68,000 & 200,000 & 2018 \\
\hline 4.0 & & & & & & Bids accepted & & & & & & & \\
\hline
\end{tabular}

